\title{
SYNTHESIS OF A NOVEL CHALCONE DERIVATIVE FROM MYRISTICIN FOR SKIN CANCER PREVENTIVE ACTIVITY
}

\author{
H. M. Ansory ${ }^{1,}$, I. N. Fitriani², S. Handayani ${ }^{3,}$ and N. Aznam ${ }^{3}$ \\ ${ }^{1}$ Department of Pharmacy, Universitas Setia Budi Surakarta, Surakarta-57127, Indonesia \\ ${ }^{2}$ Department Chemistry, Universitas Islam Negeri Walisongo Semarang, \\ Semarang-50185, Indonesia \\ ${ }^{3}$ Department of Chemical Education, Universitas Negeri Yogyakarta, \\ Yogyakarta-55281, Indonesia \\ ${ }^{\square}$ Corresponding Author: hery.ansory89@setiabudi.ac.id
}

\begin{abstract}
Chalcone with the presence of methoxy and two oxygenated substituents is predicted to have good anticancer activity. Therefore a novel chalcone derivative 3 from myristicin was synthesized through three synthesis steps 1, 2, characterized by GC-Ms, IR, and ${ }^{1} \mathrm{H}-\mathrm{NMR}$. Molecular target screening of skin cancer from the myristicin derivatives are Heat Shock Protein 90 (HSP90A), Prostaglandin Synthase 2 (PTGS2), and Dihydroorotate Dehydrogenase (DHODH). Molecular docking performed using AutoDock-Tools 1.5.6. The results showed that HSP90A, PTGS2, and DHODH were predicted as potential macromolecule targets with good interactions with myristicin derivatives for skin cancer therapy. Chalcone derivatives from myristicin are predicted as potent compounds against skin cancer molecular protein targets by docking molecular studies

Keywords: Myristicin, Chalcone Derivative, Anticancer Activity, Molecular Docking
\end{abstract}

RASĀYAN J. Chem., Vol. 14, No.3, 2021

\section{INTRODUCTION}

Myristicin (6-allyl-4-methoxybenzo-1,3]dioxole) is a major molecule in nutmeg essential oil. ${ }^{1,2}$ It represents about 9-38\%, depending on the distillate material used. ${ }^{3}$ It can be isolated by distillation at 423 $\mathrm{K}, 25 \mathrm{mmHg} .{ }^{4}$ Myristicin has an allyl group that can be converted into an aldehyde group to be a benzaldehyde derivative. This conversion has been done with similar molecules like methyl eugenol and anethole through isomerization and oxidation. ${ }^{5,6}$ These benzaldehyde derivatives from myristicin can then be reacted with methyl phenyl ketone to produce novel chalcone derivatives. Chalcones have diverse biological activities, such as anticancer ${ }^{7,8,9}$, antioxidant ${ }^{10}$, antimalaria ${ }^{11}$, and anti-allergic activities. ${ }^{12}$ Chalcones derivative structure as an anticancer correlation has been investigated and concluded that the presence of 2' oxygenated substituents and the presence of methoxy substituents are preferred structures. ${ }^{13,14}$ Therefore, we recently reported the novel chalcone derivative with the presence of methoxy and methylenedioxy substituents 3-(7-methoxybenzo[1,3]dioxol-5-yl)-1-phenylprop-2-en-1-one $\mathbf{3}$ through three-step synthesis(Scheme-1).

Skin cancer is an emerging public health issue with $40 \%$ of current cancer patients. Skin cancer contains squamous cell carcinoma (SCC), basal cell carcinoma (BCC), and malignant melanoma. SCC and BCC are two cancers of the non-melanoma skin arising from epidermal keratinocytes that correlate with prolonged exposure to the light, while melanoma of the skin affects melanocytes with intermittent exposure to the sun. ${ }^{15}$ The incidence of skin cancer is growing worldwide. Most skin cancers induced by ultraviolet radiation penetration and protection at the government and person-level advised. ${ }^{16}$ In-silico molecular docking modeled possible anticancer activities of myristicin. In this research, myristicin derivative performed molecular docking analysis toward active cancer-protein targets. A new study is also needed to discover new skin cancer compounds. One of the most successful methods of inhibiting skin cancer is to identify a particular target medication.

Rasayan J. Chem., 14(3), 1493-1498(2021)

http://doi.org/10.31788/ RJC.2021.1436312

(c) (i)

This work is licensed under a CC BY 4.0 license. 
RASĀYAN J. Chem.

Vol. 14 | No. 3 |1493-1498| July - September | 2021

Molecular docking is a method that combines small molecules with macromolecular structure and ligand of the target protein identify and fit, shape a binding pose, and have an affinity. This approach has been commonly used to research medicines and integrate molecular docking with in vitro studies that have significance for finding the new drug. In this report, we looked at the usage of molecular docking and testing of small molecular inhibitors. ${ }^{17,18}$<smiles>C=CCc1cc(OC)c2c(c1)OCO2</smiles><smiles>C/C=C/c1cc(OC)c2c(c1)OCO2</smiles><smiles>COc1cc(C=O)cc2c1OCO2</smiles><smiles>COc1cc(C=O)cc2c1OCO2</smiles><smiles>CC(=O)c1ccccc1</smiles><smiles>COc1cc(/C=C/C(=O)c2ccccc2)cc2c1OCO2</smiles>

Scheme-1

\section{EXPERIMENTAL}

\section{Material and Methods}

Myristicin (isolated results with $92 \%$ purity), potassium hydroxide, ethanol, anhydrous $\mathrm{Na}_{2} \mathrm{SO}_{4}$, chloroform, tween 80, potassium permanganate, dichloromethane, methyl phenyl ketone, sodium hydroxide, all chemical e-Merck with p.a grade. ${ }^{1} \mathrm{H}-\mathrm{NMR}$ recorded in $400 \mathrm{MHz}$ Agilent NMR spectrometer, IR recorded in IR Prestige-21, Shimadzu spectrophotometer, GC recorded in GC 2010, Shimadzu and GCMs recorded in QP-2010 Plus, Shimadzu.

\section{General Procedure of Synthesis of Isomyristicin (1)}

Myristicin and $20 \% \mathrm{KOH}$ in ethanol (1:1) was reflux for 5 hours. The result extracted by chloroform-water up to neutral $\mathrm{pH}$, and chloroform evaporated to have the reaction result. The reaction methods adopted from eugenol, anethole, and safrole isomerization reaction ${ }^{18-20}$. Yield: $87 \%, \mathrm{~m} / \mathrm{z}$, two peaks with similar Ms profile 5.88\% area and 91.40\% area (GC), Irel, \%: 192 (100), 177 (8), 161 (20), 147 (17), 131 (19), 119 (29), 103 (8), 91 (52), 77 (19), 65 (29), 53 (17), 39 (12), 27 (7).

\section{General Procedure of Synthesis of 7-methoxybenzo[1,3]dioxole-5-carbaldehyde (2).}

The mixture of 1 ( $3.90 \mathrm{~g}, 0.02 \mathrm{~mol})$, sulfuric acid $50 \%(15 \mathrm{ml})$, tween $80(0.1 \mathrm{~g})$, dichloromethane added to $50 \mathrm{ml}$, and temperature adjusted under $10^{\circ} \mathrm{C}$. Then $10 \%$ potassium permanganate solution was added dropwise into the mixture and keep the temperature. Then the reaction mixture heated to $40^{\circ} \mathrm{C}$ (till the purple color disappear). Then add sodium bisulfite $(3 \mathrm{~g})$. The result extracted by dichloromethane-water up to neutral $\mathrm{pH}$, and dichloromethane evaporated to have the reaction result. Yield: $49 \%$ m.p. $53^{\circ} \mathrm{C} .97 .47 \%$ area (GC). 
RASĀYAN J. Chem.

Vol. 14 | No. 3 |1493-1498| July - September | 2021

General Procedure of Synthesis of 3-(7-methoxybenzo[1,3]dioxol-5-yl)-1-phenylprop-2-en-1-one (3). $2(0.9 \mathrm{~g}, 0.005 \mathrm{~mol})$ dissolve in $10 \mathrm{ml}$ of ethanol, add methyl phenyl ketone $(0.6 \mathrm{~g}, 0,005 \mathrm{~mol})$, then add in dropwise $10 \mathrm{ml}$ of $30 \%$ sodium hydroxide in ethanol and keep the temperature under $30^{\circ} \mathrm{C}$. The mixture stirred for three hours. Solid results filtered and washed with water to neutral $p \mathrm{H}$. Yield: $55 \%$ m.p. $88^{\circ} \mathrm{C}$, $95.56 \%$ area (TLC)

\section{GC-Ms Analysis Method}

Helium as a carrier gas. $50^{\circ} \mathrm{C}$ of column oven temp, $300^{\circ} \mathrm{C}$ of injection temperature, split injection mode, pressure flow control, $13.0 \mathrm{kPa}$ of pressure, $79.3 \mathrm{ml} / \mathrm{min}$ of total flow, $0.55 \mathrm{ml} / \mathrm{min}$ column flow, 26.8 $\mathrm{cm} / \mathrm{sec}$ linear velocity, $3.0 \mathrm{ml} / \mathrm{min}$ of purge flow, 138.9 split ratios, Oven Temperature Program with rate $5^{\circ} \mathrm{C}$ from $50-240^{\circ} \mathrm{C}$ withholding time $5-7 \mathrm{~min}$. The mass spectrometer operated in EI mode with $250^{\circ} \mathrm{C}$ of ion source temp, $300^{\circ} \mathrm{C}$ of interface temp, $3 \mathrm{~min}$ of solvent cut time, absolute detector gain mode, and $0.80 \mathrm{kV}$ detector gain, 0 of the thresholds.

\section{Molecular Docking}

Chemical structures of 4 ligands, made of ChemDraw database manually. Three dimensional (3D) structures are HSP90 (PDB ID: 2VCJ resolution: 2.50 A), DHODH (PDB ID: 5IKQ resolution: 2.41 A), and PTGS2 (PDB ID: 2BXV with resolution of $2.15 \mathrm{~A}$ ). Macromolecules collected from the Protein Data Bank (PDB). A macromolecule was prepared using UCSF Chimera software. Docking investigations carried out using AutoDock Tools 1.5.6. Furthermore, the binding site study was performed by Discovery Studio. ${ }^{21}$

\section{RESULTS AND DISCUSSION}

The isomyristicin $\mathbf{1}$ was synthesized. GC-Ms spectra of $\mathbf{1}$ show the presence of two peaks with the same $\mathrm{m} / \mathrm{z}=192$ at $25.703 \mathrm{~min} 5.88 \%$ area and $27.057 \mathrm{~min} 91.40 \%$. It indicated that reaction product 1 has isomers. The possible isomers for $\mathbf{1}$ are geometry isomer's $\mathrm{E}$ and $\mathrm{Z}$, the reason for the two diastereoisomer's products explained by Hassam et al. ${ }^{18}$ as- "The rate of rotation in the conformation will determine the deprotonation rate $\left(\mathrm{K}_{E}\right.$ and $\left.\mathrm{K}_{Z}\right)$ so that the $E$ and $Z$ ratio of the reaction product will be related to the $\mathrm{K}_{E} /$ $\mathrm{K}_{Z}$ ratio. The configuration in the $Z$ allylic anion transition state has higher energy than the $E$ allylic anion. This is due to an unfavorable 1-3 interaction that will disturb the resonance stability of the phenyl" (Scheme2).

Then from IR spectra shows the absorption that matches to isomyristicin functional group, Table- 1 . The ${ }^{1} \mathrm{H}-\mathrm{NMR}$ spectra of 1 show the perfect match for hydrogen chemical shift. The spectrum is very clear and convincing that the target molecule has obtained Tabel-2. The appearance of $-\mathrm{CH}_{3}$ protons signal at 1.84 ppm (dd) ${ }^{4} \mathrm{~J}: 1.2 \mathrm{~Hz} ;{ }^{3} \mathrm{~J}: 6.4 \mathrm{~Hz}$ showing that the reaction was successful. The coupling value shows the $E$ geometry isomer of 1 with ${ }^{3} \mathrm{~J}=15.6 \mathrm{~Hz}$.

For compound 2 synthesized, GC spectra show the presence of one major peak at $21.246 \mathrm{~min} 97.47 \%$ area. From IR spectra show the absorption of the aldehyde functional group that indicated the reaction was successful, Table-1. Hydrogen chemical shift of 2 also shows aldehyde proton type Table-2 at $9.82 \mathrm{ppm}$.

Tabel-1: IR Spectra Absorption $\left(\mathrm{cm}^{-1}\right)$ of 1,2 and 3

\begin{tabular}{|c|c|c|c|c|c|c|}
\hline \multirow[t]{2}{*}{ Comp. } & \multicolumn{6}{|c|}{ Type of Bond } \\
\hline & $\mathrm{C}-\mathrm{H}$ & $=\mathrm{C}-\mathrm{H}$ & $\mathrm{C}=\mathrm{C}$ & $\mathrm{C}=\mathrm{C} \mathrm{Ar}$ & $\mathrm{C}-\mathrm{O}$ & $\mathrm{C}=\mathrm{O}$ \\
\hline 1 & $\begin{array}{c}2908 \mathrm{~s} \\
1357 \mathrm{~s}\end{array}$ & $\begin{array}{c}3070 \mathrm{~m}, \\
3010 \mathrm{~m}, \\
925 \mathrm{~s}\end{array}$ & $1627 \mathrm{~s}$ & $1504 \mathrm{~s}$ & $\begin{array}{c}1087 \text { s, } 1126 \\
\text { s }\end{array}$ & - \\
\hline 2 & $\begin{array}{c}2939 \mathrm{~s} \\
1342 \mathrm{~s}\end{array}$ & $\begin{array}{c}3062 \mathrm{~m}, \\
3015 \mathrm{~m}, \\
925 \mathrm{~s}\end{array}$ & $1581 \mathrm{~s}$ & $1512 \mathrm{~s}$ & $\begin{array}{l}1087 \mathrm{~s} \\
1134 \mathrm{~s}\end{array}$ & $1651 \mathrm{~s}$ \\
\hline 3 & $\begin{array}{l}2939 \mathrm{~s} \\
1265 \mathrm{~s}\end{array}$ & $\begin{array}{c}3086 \mathrm{~s}, \\
3024 \mathrm{~m}, \\
964 \mathrm{~s}\end{array}$ & $1589 \mathrm{~s}$ & $1504 \mathrm{~s}$ & $\begin{array}{l}1018 \mathrm{~s} \\
1134 \mathrm{~s}\end{array}$ & $1674 \mathrm{~s}$ \\
\hline
\end{tabular}

$\mathrm{m}=$ moderate-intensity, $\mathrm{s}=$ strong 
RASĀYAN J. Chem.

Vol. 14 | No. 3 |1493-1498| July - September | 2021
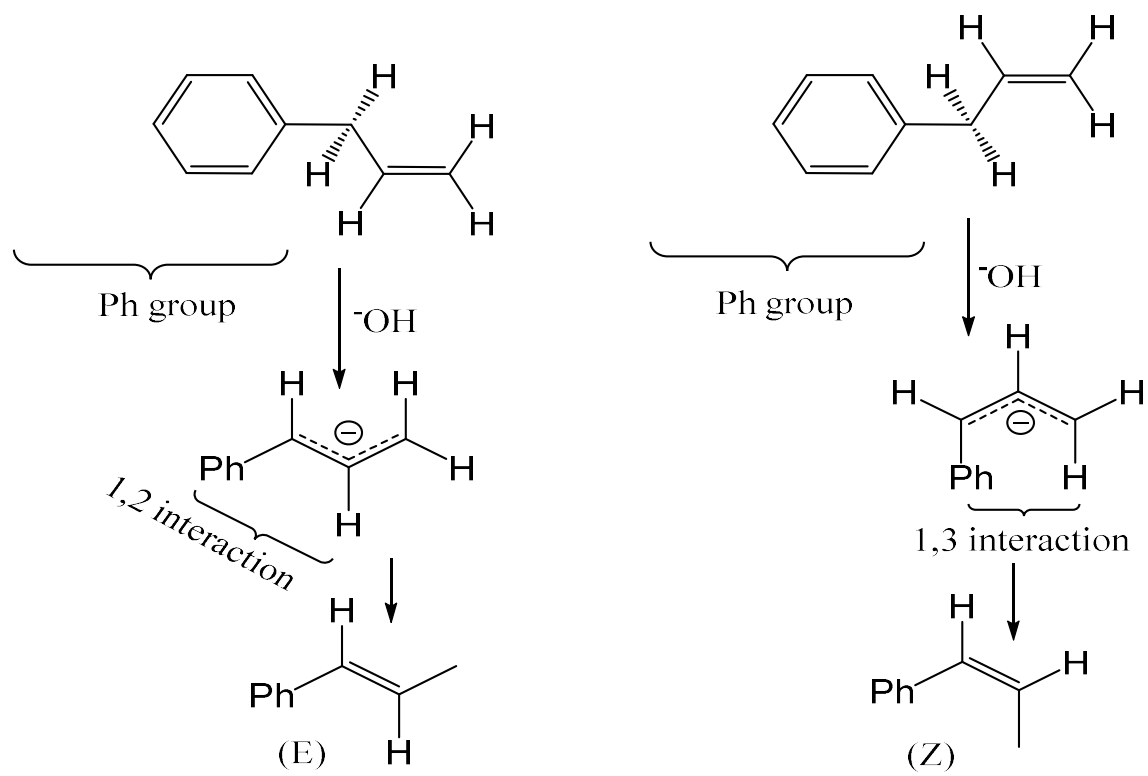

Scheme-2

For compound 3 synthesized, TLC scanner show rf $=0.22$ with $95.56 \%$ of purity. IR spectra show match absorption with molecule 3 functional group, Table-1. ${ }^{1} \mathrm{H}-\mathrm{NMR}$ spectra show that the reaction has done with the loss of proton aldehyde shift. The spectra also show that the geometry of this chalcone was $E$. It showed that the $J$ value of proton $C \alpha$ and $C \beta$ is higher than 15 . Synthesis of chalcone derivatives using piperonal has a better \%yield of $68 \%$ with $10 \% \mathrm{NaOH}$ in ethanol and the same reaction time, as a comparison. ${ }^{22}$

Table-2: ${ }^{1} \mathrm{H}-\mathrm{NMR}$ Value (ppm) of 1,2 and 3

\begin{tabular}{|c|c|c|c|c|c|c|}
\hline Comp. & $-\mathrm{OCH}_{3}$ & $\mathrm{O}-\mathrm{CH}_{2}-\mathrm{O}$ & Allyl Protons & $\begin{array}{l}\text { Aldehyde } \\
\text { Proton }\end{array}$ & $\begin{array}{c}\text { Aromatic } \\
\text { Proton (1) }\end{array}$ & $\begin{array}{l}\text { Aromatic } \\
\text { Proton (2) }\end{array}$ \\
\hline 1 & $\begin{array}{c}3.89 \mathrm{~s} \\
(3 \mathrm{H})\end{array}$ & $5.93 \mathrm{~s}(2 \mathrm{H})$ & $\begin{array}{c}1.84 \mathrm{dd}(3 \mathrm{H},=\mathrm{CH}-\mathrm{C}- \\
\left.\mathrm{H}_{3}, \mathrm{~J}=1.2,6.4 \mathrm{~Hz}\right) \\
6.07 \mathrm{dq}(1 \mathrm{H},=\mathrm{C}-\mathrm{H}- \\
\left.\mathrm{CH}_{3}, \mathrm{~J}=15.6,6.4 \mathrm{~Hz}\right) \\
6.28 \mathrm{dd}(1 \mathrm{H},=\mathrm{C}-\mathrm{H}- \\
\mathrm{Ar}, \mathrm{J}=2,15.6 \mathrm{~Hz})\end{array}$ & - & $\begin{array}{c}6.46(1 \mathrm{H}) \\
6.56(1 \mathrm{H})\end{array}$ & - \\
\hline 2 & $\begin{array}{l}3.92 \mathrm{~s} \\
(3 \mathrm{H})\end{array}$ & $6.93 \mathrm{~s}(2 \mathrm{H})$ & - & $9.82 \mathrm{~s}(1 \mathrm{H})$ & $\begin{array}{c}7.38(1 \mathrm{H}) \\
7.42(1 \mathrm{H})\end{array}$ & - \\
\hline 3 & $\begin{array}{c}3.94 \mathrm{~s} \\
(3 \mathrm{H})\end{array}$ & $6.89 \mathrm{~s}(2 \mathrm{H})$ & $\begin{array}{c}7.38 \mathrm{~d}(1 \mathrm{H}, \mathrm{C} \alpha-\mathbf{H}, \mathbf{J}= \\
15.6 \mathrm{~Hz}) ; 7.76 \mathrm{~d}(1 \mathrm{H}, \\
\mathrm{C} \beta-\mathbf{H}, \mathrm{J}=15.6 \mathrm{~Hz})\end{array}$ & - & $\begin{array}{l}7.16(1 \mathrm{H}) \\
7.24(1 \mathrm{H})\end{array}$ & $\begin{array}{c}8.01(2 \mathrm{H}) ; 7.57 \\
(2 \mathrm{H}) ; \\
7.50(2 \mathrm{H}) \\
\end{array}$ \\
\hline
\end{tabular}

HSP90 is a chaperone that plays an important role in conformational ripening and protein activity inside the substrate membrane. ATP interaction with its HSP90 contributes to some autophosphorylation tyrosine residues. Earlier screened hits show an inhibitory HSP90 effect. ${ }^{23}$

UV-B-induced tumorigenesis is related to altered metabolism, and that DHODH fuels mitochondrial respiration for DNA repair and ATP synthesis coordination. ${ }^{24}$ HSP90 is essential in regulating several cell proteins. It was a good goal for many diseases like tumors and protein misfolding disorder. ${ }^{25}$

Three compounds docked to binding sites of the protein target. The best-docked ligand in Hsp90A was 3 . The binding energy score is $-7.5 \mathrm{kcal} / \mathrm{mmol}$. The best binding score in the DHODH compound is -10.3 $\mathrm{kcal} / \mathrm{mol}$ with no hydrogen bond interaction.

The docking results between the PTGS2 protein and ligands from myristicin derivatives showed all ligands could interact with PTGS2. The lowest $\Delta$ Gbind was $\mathbf{3}$, which has a binding energy score of $-8.6 \mathrm{kcal} / \mathrm{mol}$. This compound occupies the same binding site as the native ligand. There is no hydrogen bond with amino 
RASĀYAN J. Chem.

Vol. 14 | No. 3 |1493-1498| July - September | 2021

acid residues at the binding site. Residu Tyr385 and Ser530 only have Van der Walls interaction for PGTS2 inhibitory activity.

\begin{tabular}{c|c|c|c|c|c}
\multicolumn{6}{c}{ Table-3: Docking Score and Residue Interaction of Myristicin Derivative } \\
\hline $\begin{array}{c}\text { No } \\
\cdot\end{array}$ & Compound & Macromolecule & $\begin{array}{c}\Delta \mathrm{G} \text { Binding } \\
(\mathrm{kcal} / \mathrm{mol})\end{array}$ & $\begin{array}{c}\text { Residue } \\
\text { Interaction } \\
(\text { H-bonds })\end{array}$ & Non-hydrogen Interaction \\
\hline 1 & $\mathbf{1}$ & HSP90 & -6.3 & Asn51 & Ala55, Leu48 \\
\hline 2 & $\mathbf{2}$ & HSP90 & -6.4 & Asn51, Thr184 & Ala55, Leu48 \\
\hline 3 & $\mathbf{3}$ & HSP90 & -7.5 & Asn51 & Ala55, Leu48 \\
\hline 4 & $\mathbf{1}$ & DHODH & -8.0 & Ser305 & $\begin{array}{c}\text { Tyr256, Val143, Pro52, } \\
\text { Val134 }\end{array}$ \\
\hline 5 & $\mathbf{2}$ & DHODH & -7.4 & Asn145, Ser305 & Tyr356, Val143 \\
\hline 6 & $\mathbf{3}$ & DHODH & -10.3 & - & $\begin{array}{c}\text { Val143, Thr360, Ala55, } \\
\text { Ala59 }\end{array}$ \\
\hline 7 & $\mathbf{1}$ & PTGS2 & -6.5 & Ser530 & $\begin{array}{c}\text { Val523, Leu352, Ala527, } \\
\text { Gly526, Val 349 }\end{array}$ \\
\hline 8 & $\mathbf{2}$ & PTGS2 & -6.5 & Ser530 & $\begin{array}{c}\text { Val523, Ala527, } \\
\text { Leu352, Gly526 }\end{array}$ \\
\hline 9 & $\mathbf{3}$ & PTGS2 & -8.6 & - & $\begin{array}{c}\text { Val523, Ala527, Leu359, } \\
\text { Leu531, Val349 }\end{array}$ \\
\hline
\end{tabular}

\section{CONCLUSION}

A novel chalcone derivative 3 from myristicin synthesized through three synthesis steps $\mathbf{1}, \mathbf{2}$, characterized by GC-Ms, IR, and ${ }^{1} \mathrm{H}$ NMR. Compound 3 at HSP90A has $\Delta$ Gbind $-7.5 \mathrm{kcal} / \mathrm{mol}$. The docking results between PTGS2 and DHODH proteins with ligands from myristicin-derived compounds showed that almost all ligands could interact with both targets. Ligan has the lowest $\Delta$ Gbind value and has the best interaction of $-10.3 \mathrm{kcal} / \mathrm{mol}$ and $-8.6 \mathrm{kcal} / \mathrm{mol}$ in DHODH and PTGS2. Myristicin chalcone derivatives are predicted as potent compounds against skin cancer molecular protein targets by docking molecular studies.

\section{ACKNOWLEDGEMENT}

The author would gratefully like to acknowledge "Kementerian Riset dan Teknologi / Badan Riset dan Inovasi Nasional (RISTEK-BRIN)", Indonesia for financial support SK. No. 228/SP2H/LT/DRPM/2019, 001/LPPM-USB/Pekerti/V/2019.

\section{REFERENCES}

1. Muchtaridi, A. Subarnas, A. Apriyantono and R. Mustarichie, International Journal of Molecular Sciences, 11(11), 4771(2010), https://doi.org/10.3390/ijms11114771

2. J. Y. Lee and Park, Molecules, 16(8), 7132(2011), https://doi.org/10.3390/molecules 16087132

3. H. M. Ansory, B. Purwono and H. S. Sastrohamidjojo, Jurnal Farmasi Indonesia, 12(2), 127(2015)

4. H. M. Ansory, E. N. Sari, A. Nilawati, S. Handayani, and N. Aznam, In Proceedings of The Proceedings of the 2nd Bakti Tunas Husada-Health Science International Conference (BTH-HSIC 2019), Indonesia, pp.138-142 (2020), https://doi.org/10.2991/ahsr.k.200523.034

5. J. Yu, M. Shen, L. Deng, L. Gan and C. Ha, Chemistry of Natural Compounds, 48(4), 541(2012), https://doi.org/10.1007/s10600-012-0304-3

6. J. Molleti, and G. D. Yadav, Organic Process Research and Development, 21(7), 1012(2017), https://doi.org/10.1021/acs.oprd.7b00127

7. B. Srinivasan, T. E. Johnson, R. Lad and C. Xing, Journal of Medicinal Chemistry, 52(22), 7228(2009), https://doi.org/10.1021/jm901278z

8. A. Modzelewska, C. Pettit, G. Achanta, N. E. Davidson, P. Huang and S. R. Khan, Bioorganic \& Medicinal Chemistry, 14(10), 3491(2006), https://doi.org/10.1016/j.bmc.2006.01.003

9. A. N. Kristanti, H. Suwito, N. S. Aminah, K. U. Haq, H. D. Hardiyanti, H. Anggraeni, N. Faiza, R.S. Anto and S. Muharromah, Rasayan Journal of Chemistry, 13(1), 654(2020), https://doi.org/10.31788/RJC.2020.1315534 
RASĀYAN J. Chem.

Vol. 14 | No. 3 |1493-1498| July - September | 2021

10. C.L. Miranda, J.F. Stevens, V. Ivanov, M. McCall, B. Frei, M.L. Deinzer, et al., Journal of Agricultural and Food Chemistry, 48(9), 3876(2000), https://doi.org/10.1021/jf0002995

11. J. N. Domınguez, J. E. Charris, G. Lobo, G. N. de Domınguez, M. M. Moreno, F. Riggione, et al., European Journal of Medicinal Chemistry, 36(6), 555(2001), https://doi.org/10.1016/S0223$\underline{5234(01) 01245-4}$

12. J. R. Dimmock, D.W. Elias, M. A. Beazely and N. M. Kandepu, Current Medicinal Chemistry, 6(12), 1125(1999), https://doi.org/10.1002/chin.200006265

13. M. Go, X. Wu and X. Liu, Current Medicinal Chemistry, 12(4), 483(2012), https://doi.org/10.2174/0929867053363153

14. H. Hegde, S. L. Gaonkar, N. P. Badiger and N. S. Shetty, Rasayan Journal of Chemistry, 13(3), 1744 (2020), https://doi.org/10.31788/RJC.2020.1335669

15. D. K. Yadav, S. Kumar, E. Choi, S. Chaudhary and M. Kim, Frontiers in Chemistry, 8, 250(2020), https://doi.org/10.3389/fchem.2020.00250

16. S. Ziaj, F. Tseliou, D. Datta and R. A. Abbott, British Journal of Dermatology, 184(4), 764(2020), https://doi.org/10.1111/bjd.19676

17. Y. Li and X. Zhang, Journal of Dermatological Treatment, 31(4), 1(2020), https://doi.org/10.1080/09546634.2020.1756201

18. Nursamsiar1, M. Siregar, A. Awaluddin, N. Nurnahari, S. Nur, E. Febrina and A. Asnawi, Rasayan Journal of Chemistry, 13(1), 690(2020), https://doi.org/10.31788/RJC.2020.1315577

19. M. Hassam, A. A. Nour, A. M. Satti and K. S. Kirollos, International Journal of Chemical Kinetics, 14(4), 351(2015), https://doi.org/10.1002/kin.550140403

20. M. Halpern, M. Yonowich-Weiss, Y. Sasson and M. Rabinovitz, Tetrahedron Letter, 22(7), 703(1981), https://doi.org/10.1016/S0040-4039(01)92529-8

21. M. Halpern, Y. Sasson and M. Rabinovitz, The Journal of Organic Chemistry, 48(7), 1022(1983), https://doi.org/10.1021/jo00155a018

22. V. Vijayakumar, N. Radhakrishnan, and P. Vasantha-Srinivasan., Research Journal of Pharmacy and Technology, 13(6), 2777 (2020), https://doi.org/10.5958/0974-360X.2020.00493.X

23. Amarnath Singadi and K. Venkateswarlu, International Journal of Advances in Pharmacy and Biotechnology, 6(1), 4(2020), https://doi.org/10.38111/ijapb.20200601002

24. M. A. Al-Sha'er, I. Mansi, M. Khanfar and A. Abudayyh, Journal of Enzyme Inhibition and Medicinal Chemistry, 31(sup4), 64(2016), https://doi.org/10.1080/14756366.2016.1218485

25. M. Hosseini, L. Dousset, P. Michon et al., Oncogenesis, 8(10), 1(2019), https://doi.org/10.1038/s41389-019-0161-z

26. F. Schopf, M. Biebl and J. Buchner, Nature Reviews Molecular Cell Biology, 18(6), 345(2017), https://doi.org/10.1038/nrm.2017.20

[RJC-6312/2020] 